\title{
Influence of School Socialization Styles on Students' Self Esteem at Secondary School Level
}

Mrs. Noor E Ain*

Dr. Qurat-ul-Ain Hina*

\begin{abstract}
The study's major objectives were to explore the major prevailing socialization styles of the Secondary schools, to explore the levels of self-esteem of Secondary school's students and to assess the effect of socialization styles on self-esteem. This study was delimited to the class 10th students of the secondary Schools working under Federal Directorate of Education Islamabad. Conceptual framework was designed by taking theory of school socialization styles (Pellerin, 2005) was and theory of self-esteem (Dharsini \& Jeebaseelan, 2017). There were two variables in the study. (a) School socialization styles (b) Self-esteem. School socialization style was treated as independent variable whereas students' selfesteem were dependent variables. All the students of 10th class of the schools working in six sectors of Islamabad capital territory under the umbrella of Federal Directorate of Education Islamabad, which constitute number of 12810 ( Boys 5231, Girls 7579) were considered as the population of the study. $10 \%$ of the total numbers of students that is 12810 students of the secondary schools working under Federal Directorate of Education were further selected as sample of the investigation. Proportionate random sampling technique was used. $10 \%$ boys i.e. 524 boys and $10 \%$ of the girls i.e. 758 were proportionately selected as sample for the study. Self-developed scale based on the parameters given by Pellerin, (2005) was used to assess school socialization style. self-esteem test used by Dharsini and Jeebaseelan (2017) was adapted. Data was collected by the researcher personally. Research Findings showed that there are significant effects of school socialization styles on secondary school students' self-esteem at secondary school level. Demandingness was found the most prevailing style of school socialization. It was revealed from data analysis that majority of the students are at the medium level of self-esteem.
\end{abstract}

Keywords: Socialization styles, students' self-esteem at secondary school level, effect of socialization styles on students' self esteem

\section{INTRODUCTION}

Future generations are nurtured in schools therefore schools are considered as nurseries where children's personality attributes and habits are refined and shaped. Abdullah (2000) mentioned that other than academics, students also acquire in school how to behave and interact with others in an efficient and effective way to be known as civilized and welladjusted members of the society. Therefore, schools role in socializing the children cannot be overlooked. Socialization is a course of action in which an individual obtains personal identity, social skills and knowledge, which are required to move and interact with others in a society. Students are taught curriculum through academic practices in the schools, during the course of academic practices students also acquire social rules and expectations through interaction with others in school. Students develop and grow in many ways. They grow physically and mentally. The socialization process includes learning how to be with others and to be with self (Abdullah, 2000).

Society is going through rigorous social changes. Individuality of the students is affected by

${ }^{*}$ PhD Scholar, National University of Modern Languages Islamabad.

${ }^{* *}$ Assistant Professor, National University of Modern Languages Islamabad.

$=$ International Research Journal of Education and Innovation 
depressing and injurious realities that have broader expansion outside the school (Nurlanova, 2014). According to Nurlanova (2014) socialization is a procedure of nurturing personality characteristics that are shaped by social status. Socialization also refers to mastery of an individual of system of values, standards and knowledge which are suitable in his society. These values, standards and knowledge permit him to work and move in the society as an exclusively equal member (Oswalt, 2016).

Since ages school has been remained the most regular and constant conventional agent of socialization. The school is such a beneficial socializing driving force that it has been provided evidences for socializing cluster of children on explicit values and skills in society. In current era this social institution is anticipated to both train the individuals possessing basic social values and achieving good grades in academics (Khan, Tufail and Husain, 2014)

Schools serve as social institutions therefore school plays an important and fundamental role in the social adjustment of an individual. Every school has its own distinct socialization environment and that distinct environment is regarded as school socialization style. School Socialization styles i.e. demandingness and responsiveness were introduced by Pellerin (2005). Students' personality is greatly influenced by School Socialization styles especially in middle and high schools as at this level of student life, they get more opportunities to interact with their fellows, teachers and other school staff (Kerby 2015)

School socialization style is an appreciable gadget for photographing the complex realities of schools as it demonstrates how different socialization styles influence students' behavior and attitude (Ayers, 2001). School socialization styles provide students with structure, support, independence and participation which help in promoting self esteem of students. School socialization styles providing attribute of structure, support, independence and participation gratify students' psychological requirement of being valued.

According to Murk (2013) self esteem of the students nurtures in social environment of school. Self esteem is regarded as self worth or self respect. It has a great role in success and failure of an individual. As per opinion of Murk (2018) individuals possessing low self esteem feel depressed and dejected. This feeling can lead people to make wrong decisions or choices, or they fail to work and make life equal to their dejected approach. Similarly an individual with high self esteem can also be of no good as his high self esteem may harm his personal relationship and it can also cause behavior disorder. Too low and too high self esteem both can be harmful. Therefore it is best to thumb equilibrium somewhere in the core. A rational but optimistic view of oneself is considered as the best.

School socialization styles play important role in the development of a balanced self esteem, neither too low nor too high. In school students work together with peers and teachers (Haruna, 2014). Teachers appreciate and encourage them on doing good and right things and instruct and guide them to avoid and leave bad habits. Teachers know strength and weaknesses of their students and guide them accordingly to improve on themselves (Holden, 2018). Interaction with other fellow students, belong to different families, ethnicities, social setup etc. helps them in learning how to deal with different people in an ideal manner. These practices are the essential elements of the school socialization styles. A school possessing these qualities in its social context can groom an individual as a well adjusted future citizen (Imam, 2012).

Schools managers and teachers arrange the pitch for their students' academic experiences

= International Research Journal of Education and Innovation 
throughout their school life for cultural, social, ethical and psychological grooming. School socialization copes with acquiring norms, value, and knowledge related to academics and practical psycho- social life. School socialization is a vigorous active agent who at a time boast moral of the learners for the development of a better self esteem and at the same time motivate students to show better academic results.

Baumeister et al. (2003) declare self-esteem as self - concept of an individual. It is regarding the view of an individual about his worth and deprivations. It evaluated the conceptions of the person about his life aspects and abilities. Orth \&Ribins (2014) stated that as a subjective evaluation/ assessment it has to do much with understanding of the achievement and how much one is confident about himself. The positivity of the self-esteem can be witnessed in one's achievements at academic and behavioral level. It is about how an individual feels and adjust according to the need. The level of other skills like confidence in completion of a task are among the few characteristics of positive personality.

Parameswari (2011) declare is as an association with positive self-esteem. Over the time, the term self-esteem was evolving throughout the historic eras. Similarly, William James (1890), indicated it as a dynamically processed phenomenon. In his views, it is directly linked with failure and the success of an individual or a contrast in some ways. One comperes who he is with who he should be. In the same way, Robert White (1963) declared it as a development through gaining experiences with external and internal sources. Internal source are one's achievement or accomplishment and external is how they are affirmed by other individuals. The society, family and cultural influence on the individuals develop one's attitude in both ways negative and positive.

However, in views of Rosenberg (1979), the interpersonal relationship matters in this regard. Stanley Coppersmith in 1967 declared it as something constructed or received from the parentage. Similarly, Nathaniel Branden in 1969 defined a needed thing for human. If a person lacks self-esteem will likely possess few negative traits like abusing, anxious, and depressive. Lawrence has suggested in 1973 that the self-esteem as an assessment of individual's series of values. The individual promotes them with the passage of time, and it is about the developmental aspects of one's personality i.e. abilities one possess, attribute and appearances. It is about how they perceive themselves and by other adults in the society. It is the interactions with other adults in a society which enables children to form and develop self-esteem with a perception of fellows. They consider the impressions and admirations of the others in a context which enables them to question their abilities ultimately. Considering the Lawrence's suggestion, it is about how one respect himself.

Every one of us has the values about ourselves and evaluations are done on the basis of actions, abilities and behaviors. Von Der Haar (2005) considers self-esteem as a placement of oneself. (20080 view self-esteem as measurement (Larsen \& Buss) of moderation and correlation of the areas of person. Murk (2006) described as self-worth and competence integrated as sum. It answers the questions related to the capabilities of a person. Just few years ago, the term self-esteem gained popularity in education and society. Once a person understands his worth, works accordingly to sustain in the society and take initiatives to improve his capabilities according to the acceptance of the other members of the society. The overall growth in education, academics and social status is witnessed when an individual is improving. However, it is considered as a critical attribution of a person according to 
Coopersmith (1967) because of the individual's overt behavior toward his personality. The person with adequacy of self-esteem does not like to be admirer of his personality, nor does he want other to praise or admire his traits. Furthermore, it is related to the responsibility one takes on his shoulders. Horrocks and Jackson (1972) state self-esteem as self-security and capability of being responsible for the actions. Similarly, it is the way through which an individual gets succeed and become not harmful to any other nor for himself. It is a driving force toward success (Crocker \& Park, 2003).

It is very much important for children to learn socialization skills in school. It requires patience and effort to guide and train children to think of others and themselves. Children should be taught to move effectively in the public, to interact with others in a healthy, constructive and positive way. With the rationale to develop children as responsible, winning and successful adults, it is necessary to give them ample opportunities of socialization in school. Socialization helps an individual to adjust well in society and boast self esteem. Academic achievements are also impacted by socialization. Keeping in view the significance of school socialization styles the researcher chose to explore school socialization styles and its effect on self esteem of the students.

In Pakistan education system good academic results is the only focus. Numbers, percentage and grades are the only focus of the schools and teachers and very less attention, equal to none is paid to develop positive the self esteem of the students. School managers and teachers are generally not aware of the school socialization styles and therefore do not consider it necessary for the positive built of self esteem. Therefore this paper is initiated keeping in view the current practices of the schools, to probe the effect of school socialization styles on students' self-esteem.

\section{Research Objectives}

1. To explore the main widespread socialization styles of the Secondary schools.

2. To assess the effect of school socialization styles on self esteem of the Secondary school students.

\section{Research Methodology}

This was a quantitative co relational research. Quantitative procedures were taken up to portray conclusion from cause and effect analysis of the views collected from the respondents of the research to find out the effect of school socialization styles on students' self-esteem at secondary school level. Analysis made quantitatively helped the researcher to achieve concrete practices and certain stratagems which would be recommended further for schools that the researcher believed most effectual for school socialization style. School socialization style was treated as independent variable whereas student'sself-esteem were dependent variables. Thus, this study was co relational study. In co relational study the relationship of independent and dependant variables are measured using scientific method with appropriate statistical analysis.

Current study is descriptive in nature based on quantitative data. Function of descriptive research is to investigate the prevailing practices, overriding problems, existing situations and unanswered issues faced by the general public. Therefore, the research design was based on collection of information about prevailing practices related to School Socialization styles 
and its analysis for the assessment of the effectiveness of the positive learning environment and for the development of the self-esteem at secondary school's students. 12180 students of $10^{\text {th }}$ class of the schools working in six sectors of Islamabad Capital Territory under the administrative control of Federal Directorate of Education Islamabad, which constituted number of 12810 students. Among 12810 there were 5231 Boys 7579 girls. These 12810 students were the population of the study. Proportionate random sampling technique was used. $10 \%$ of the total number of boys i.e. 524 boys and $10 \%$ of the total number of the girls i.e. 758 girls were proportionately selected as sample of the study.

\section{Results}

Table 1 Major Prevailing Socialization Styles of the Secondary Schools

\begin{tabular}{llll}
\hline Variables N & Mean & Mean of Mean Std. Deviation
\end{tabular}

\begin{tabular}{llllll}
\hline Demandingness & & 1320 & 102.3422 & 4.25 & 12.44068 \\
& $\begin{array}{l}\text { Academic } \\
\text { Press }\end{array}$ & 1320 & 52.4977 & 4.37 & 6.26227 \\
& $\begin{array}{l}\text { Disciplinary } \\
\text { Climate }\end{array}$ & 1320 & 49.8422 & 4.1 & 7.11854 \\
Responsiveness & 1320 & 90.2451 & 4.1 & 14.25294 \\
& $\begin{array}{l}\text { Teacher } \\
\text { Support }\end{array}$ & 1320 & 49.4605 & 4.1 & 8.26026 \\
& $\begin{array}{l}\text { Teacher } \\
\text { Student } \\
\text { Relationship }\end{array}$ & 1320 & 40.7845 & 4 & 6.89463 \\
Socialization Styles & & 1320 & 192.5873 & 4.1 & 25.16007 \\
Valid N (listwise) & 1320 & & & \\
\hline
\end{tabular}

Table 1 indicated the major prevailing style of school socialization. Mean of Socialization style related to demandingness was 102.3422 whereas mean of mean was 4.25 . Which declared demandingness as the most prevailing school socialization style. There were two sub variable so demandingness i.e. academic press and disciplinary climate. Academic press scored mean of 52.4977 and 4.37 mean of mean. Whereas disciplinary climate score mean of 49.8422 and 4.1 mean of mean. Under demandingness, academic press was the most prevailing style of school socialization. As apparent form the name in demandingness students stated that schools environment is very demanding in nature. Teachers and school head expected from them to work hard and to spend more time on acquisition of knowledge. To bring perfection in academics and for brilliant achievement and to buck them up, teachers encouraged them by using motivational statements like "you can do it." Teacher's expected from their learners

$=$ International Research Journal of Education and Innovation $=[26]=$ 
that they should study a lot and they should have mastery of the course content. To get high grades in exam teachers compelled them to cram and learn all the content. Along with cramming and revising the course content teachers occasionally focused on their comprehension of the course content. Student's responses expressed that for good academic achievement their teachers used different strategies other than written test like discussion, quizzes and oral presentations for learning and revision of the content material. To some level teachers also made efforts for the conceptual clarity of their students. Students were of the view that teachers created pressurized and forced environment for learning of the content material. Along with academic achievement teachers wanted their students to be disciplined. Disciplinary environment refers to overall environment of the school and classroom. Students were of the view that class rules had been designed to discipline them and to bring sophistication in their behavior. These rules had been designed with student's participation. They had been scolding by the teachers if any rule is violated by them. Very few teachers tried to promote self-disciplined environment most of them believed in the forced disciplined environment. School socialization style related to responsiveness scored mean of 90.2451 and mean of mean was 4.1. Sub Variables of the responsiveness i.e. teachers support and teacher-student relationship scored mean of 49.4605 and 40.7845 respectively. Whereas mean of mean of these variables were 4.1 and 4 . Responsiveness refers to the degree of supportiveness, trusting and warm relationships between teachers and the students. Teachers support submits supportive attitude and behavior of the teachers during teaching learning process. Students' responses displayed that few teachers provided them opportunities to express their learning difficulties and continue teaching until every student learn. Generally teachers confer their mistakes privately and acknowledge and appreciate their good work publically. Rarely had they been provided guidance by their teachers in the solution of their problems. They had not been guided and asked by their teachers for any other reference material for their side learning only texts books were the focus of their teacher's attention. As far as teacher's student's relationship was considered, by and large teachers are interested in the wellbeing of their students but they are diffident to give individual attention in the solution of student's personal problems. Rarely do they give patience listening to their students problems. However teachers felt pride in the success of their students and give them credit for their good work.

Table 2

Effect of Socialization Styles on Self Esteem of the Secondary School Students

\begin{tabular}{llllll}
\hline $\begin{array}{l}\text { Independent } \\
\text { Variable }\end{array}$ & $\begin{array}{l}\text { Dependent } \\
\text { Variable }\end{array}$ & R Square & $\begin{array}{l}\text { B } \\
\text { (Coefficient) }\end{array}$ & $t$ & Sig
\end{tabular}

\begin{tabular}{llllll}
\hline School & Self Esteem & .132 & .164 & 14.74 & .000 \\
Socialization & & & & & \\
Styles & & & & & \\
\hline$* P<0.05$ & & & &
\end{tabular}

a. Dependent Variable: Self Esteem

b. Independent Variable: School Socialization Styles

= International Research Journal of Education and Innovation 
Table 2 displayed that $\mathrm{R}^{2}$ Value was .132. That signifies that the independent variable (School Socialization Styles) described 132\% variation in students 'self-esteem and the rest was due some other factor. Hence, in the coefficient $(\beta=.164)$ it displays that this effect was statistically significant at 0.05 level of significance. Thus the hypothesis there is no statistically weighty effect of school socialization styles on student esteem of the secondary school students' is excluded.

\section{Recommendations}

1. It is recommended that teachers and school heads may expect from their students mastery of the course content to show good academic performance by providing interactive learning environment. Where students have hands on activity based and conceptual learning.

2. To maintain discipline and standardize students' behavior and ethos it is recommended to school heads and teachers may adopt proactive approach rather than reactive approach.

3. It is recommended that teachers may give sufficient opportunities to their students to be active contributor in teaching learning process. They may frequently arrange formative assessments of the students to determine their leaning and adopt remedial measures to recover and overcome academic weaknesses. Cramming of the course content without comprehending it, can be avoided by providing learning participative teaching learning environment.

4. It is recommended that teachers may use intrinsic motivational strategies to urge their students to participate actively in teaching learning process. To make them to pay full concentration during teaching learning process, time to time questions may be asked by the teachers, and if pupils ask any questions, they may be welcomed by the teachers.

5. Achieving good grades in external examinations is through a genuine demand but to pursue good grades it is recommended that the comprehension of the content material may not be ignored and teachers may adopt strategies like effective use of teachings aids, frequent testing, keeping track of students' academic weaknesses and taking in time remedial measures, extra coaching and drilling etc. for learning and comprehension of the students and to produce good grades in external examination.

6. It is recommended that in case of any mistake done by the students, teachers may not focus on the person but on the action. The focus of logical consequence is always the action not the person's character. For example teachers may avoid saying "you are so careless and irresponsible" rather they may say, "What you did was carelessly done, I believe in you that you can do better than this. We are come up with a solution to fix it for you."

7. Findings proved responsiveness as the $2^{\text {nd }}$ best prevailing school socialization style. It is recommended that in start of the session teachers may try to know their students name as quickly as possible. Teachers may take time to converse in isolation with each student. Teachers can do this by setting a target for talking one to one with every student every day or whatever is feasible. They may ask about how they do with the learning and content material and skills in the course or they may ask about free time activities. For example, they may ask students about their extracurricular activities, interests and 
hobbies.

8. As apparent from findings that school socialization style related to academic press has significant effect on students 'self-esteem therefore it is recommended that teachers may appreciate students' academic accomplishments. Acknowledge and praise them even on small achievement. Praise them privately and in front of their fellows. Accept individual differences and teacher may try to know strengths and different learning styles of the students and plan their lessons accordingly which can cater the needs of every child and foster the unique abilities of every child. 